The Causal Relationship between Interest Rate and Investment in Egypt: ARDL Approach for the period 1980-2018

\author{
العلاقة السبيية بين سعر الفائدة والاستثمار في مصر : طريقة التباطؤ الموزع في الاحدار

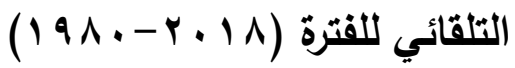

\section{Saif Sallam Alhakimi*}

Professor of International Economics

University of Bisha, Bisha, KSA

University of Hodeidah, Yemen

saifali@ub.edu.sa

\author{
Talat Rashad Shama \\ Assistant Professor of Finance \\ University of Bisa, Bisha, KSA \\ Al Azhar University, Egypt \\ tshma@ub.edu.sa
}

Keywords: Interest Rate, Investment, Causality, ARDL, Bound Testing, VECM

*Correspondent Author 


\title{
The Causal Relationship between Interest Rate and Investment in Egypt: ARDL Bound Testing for the period 1980-2018
}

\author{
العلاقة السبية بين سعر الفائدة والاستثمار في مصر : طريقة التباطؤ الموزع في الاحدار التلقائي للفترة \\ $(r \cdot 1 \Lambda-19 \Lambda \cdot)$
}

\begin{abstract}
Studying the role of interest rate to motivate investment has seen increasing interest worldwide, especially in developing economies. However, statistics have shown that investment in Egypt has been moderate during the period (1980-2018). Study data collected from the World Bank and International Monetary Fund databases. It also ensured that the time series were made balanced and interconnected, and then the Auto Regressive Distributed Lag (ARDL) method used in the analysis. The empirical results indicate both, presence of long-run Cointegration between the investment and interest rate, and interest rate granger causes investment, which is our primary concern of this research. The study recommends the Egyptian government reconsidering many of the general state policies, including investment policies, financial and administrative governance, and monetary policy that focuses on maintaining a balanced interest rate that improves and motivate the investment environment.

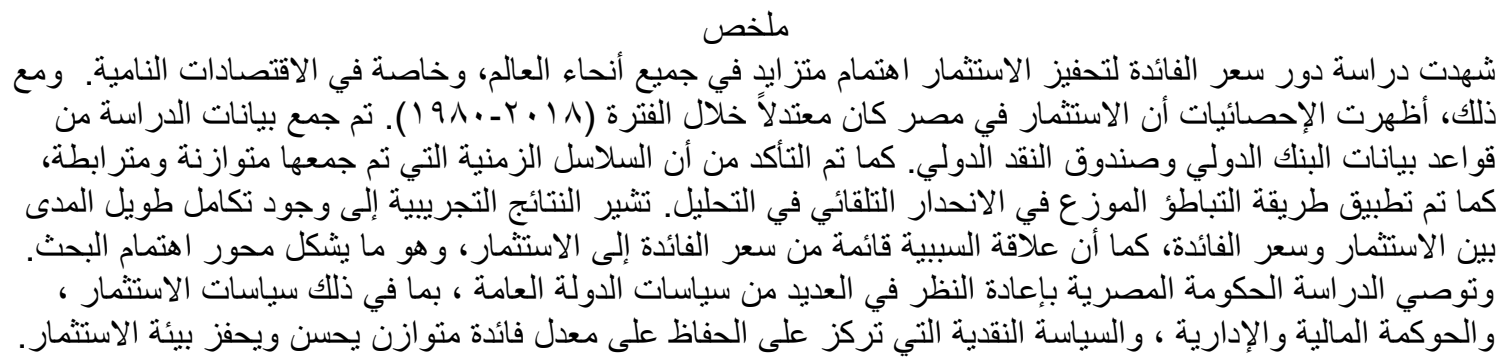

Keywords: Interest Rate, Investment, Causality test, ARDL, Bound Testing, VECM.

الكلمات المفتاحية: سعر الفائدة، الإستثمار، إختبار السبيية، التباطؤ الموزع في الانحدار التلقائي، الإختبار المقيد، نموذج تصحيح خطأ المتجه 


\section{Introduction}

Interest rate is one of the monetary policy tools that contribute to building macroeconomic policy regardless of the differences of point of view among economists. The classics see that monetary policy is the central axis in the macroeconomic system, while the Kenyans see that fiscal policy is the basis in the macroeconomic policy. Modern monetarism, led by Milton Friedman, understands that monetary policy is the focus of macroeconomic policies, while Walter Heller Club mixes monetary and fiscal policy in building general economic policies.

Classic economists argue that the interest rate is a necessity that motivates individuals and institutions to save and form the essential capital accumulations for the growth of the economy. The demand for investment changes inversely concerning the interest rate and increases with the decrease in the interest rate and decreases with its rise. In contrast, the Keynesian theory, according to the expansionary monetary policy that a reduction of real interest rates stimulates investment Who pays production and employment and increases income, and in recessions despite an increase in the money supply that lowers the interest rate. Furthermore, the weak desire of investors, and the lack of confirmation of demand for products, has made investment less sensitive to the change in the interest rate. For the transition, because there are other variables such as consumption that changes with the difference in the interest rate and is inversely proportional to the interest rate in favor of the investment, and Friedman believes that it is better to change the amount of money instead of interest rates.

Investment is the addition of new production capacities to existing productive assets in society, by establishing new projects, expanding into existing projects, 
replacing or renewing plans that have expired, or purchasing securities for new projects.

Investment in any economy depends on the availability of two necessary tapes, namely the existence of an investment opportunity with a stimulating benefit and the presence of an investor willing to invest. It requires an adequate condition, which is the incubating and stimulating investment environment.

In Egypt, interest rates represent one of the tools used by the Central Bank of Egypt in monetary policy, especially after the promulgation of Law 120 of 1975 . It authorized the Central Bank's Board of Directors to set discount rates and credit and debit interest rates without being bound by the limits stipulated in any other law (the maximum was $7 \%$ in the civil law, which ranged from $4 \%$ to $6 \%$ ). On January 3, 1991, the liberalization of the interest rate applied, and each bank was able to determine its interest rate, (Arab Corporation for Guaranteeing Investment and Export Credit Reports).

The interest rate changed during the period from 1980: 2018, as it developed before the economic reform until it reached $19 \%$ in 1990 and then reached $20.3 \%$ in 1992 and decreased until it reached $13 \%$ in 1998 and ranged between $11 \%$ to $20 \%$ until 2019 , and notes the high cost of financing for the private sector For weakness compared to the most important actors in the world, whether the European Union, America, China, Japan or the United Kingdom, to reach $11.5 \%$ on average during the period 2010 to 2015 , and in parallel, the period from 1980 to 1990 saw the highest ratio of investment to GDP, where the rate ranged between $20 \%$ To $35 \%$, then the percentage decreased during the period from 1991: 2012 to from $16 \%$ to $22 \%$ and since 2013 , the ratio of investment to the gross domestic product does not exceed $14 \%$, then it began to 
grow with the economic reform program from 2016 to 2019 (Egyptian Central Bank Reports, 2010-2016).

\section{Problem Statement}

Developing countries face enormous challenges to achieve real and sustainable development due to limited and scarce economic resources. These countries seek to improve the available resources in addition to enhancing investment as a significant contributor to economic growth. Developing countries differ in the efficiency of using the interest rate to motivate investment. That is why this paper seeks to determine to which extent interest rate causes investment.

\section{Research Question}

This study addresses an important question;

\section{Does the interest rate cause investment in Egypt?}

\section{Research Objectives}

This study conducted with the primary objective of investigating the causality relationship between the interest rate and investment in Egypt. More specifically, it aims to:

1- determine the long-term relationship between the interest rate and investment in Egypt;

2- examine the short-term relationship between foreign aid and investment in Egypt;

3- test the causality patterns between the interest rate and investment in Egypt.

\section{Research Importance}

The importance of this research consists of two folds; 1) revealing the significant contribution of foreign aid to accelerate economic development, and 2) 
introducing viable recommendations to assist the policymakers in developing their strategic plans in terms of rationalizing the use of interest rate to motivate investment.

\section{Research Methodology}

The paper implements the Auto Regressive Distributed Lag (ARDL)-Bounds testing approach to analyze maintaining the time series properties in terms of stationarity, and Pairwise Granger Causality Tests to check for causality among the two variables.

\section{Literature review}

The nexus between inflation, interest rate, and investment has been discussed by many research work. These studies were empirical and drew various inferences regarding the association between the rate of interest and investment.

The results of the studies of the relationship between the interest rate and investment vary in several directions, namely:

a) Studies that confirm the existence of a non-linear relationship between the interest rate and investment and change from positive to negative according to interest rate rates, including (Lugo, 2008) the existence of the inverse relationship between the interest rate and investment at low rates of return, and the publication The International Monetary Fund research paper (Greene \& Villanueva, 1991), to determine the factors affecting investment in 23 developing countries during the period (1987: 1975) and concluded that the investment rates of developing countries are affected by a number Among the macroeconomic variables, namely, inflation and external debt burdens have a negative impact on private investment, while economic growth rates and the level 
of per capita income and the general investment rate have a positive effect on private investment, and the existence of an inverse relationship between real interest rates and individual investment rates, and the Bader \& Malawi, 1010, study confirmed by applying to Jordan during the period from (2005: 1990) by studying the joint integration between the investment level, the real interest rate and the income level, that there is a negative reflection of the high interest rate on the investment, when the interest rate rises $1 \%$ it goes down level The investment is $44 \%$, and a positive reflection between the income level and the investment level, but the effect of the interest rate on the investment level is higher than the influence of the income level.

b) Studies that show that there is no impact of the interest rate on investment or its effect is weak, including a study (Osundina \& Osundina, 2014), applied to Nigeria during the period $(1980: 2010)$ by examining the relationship between the interest rate and investment spending using variables such as the interest rate Investment, government spending, public debt, the exchange rate, and gross domestic product at the cost of factors of production, showing that there is no relationship between the interest rate and investment spending, while a study (Sharbe \& Suarez, 2015), confirmed where he directed a set of survey questions to 550 managers. Finance in some U.S. companies in December 2012 after excluding non-profit companies, government entities and financial companies, in order to test the sensitivity of investment plans to interest rates, and I found that in most companies, their investment plans are insensitive to interest rate decreases, but the sensitivity is more significant in higher interest rates, And it is more evident in companies that do not pay much attention to financial barriers or do not plan to borrow in the short term or expect higher growth figures, this is confirmed by (Dimson, et at , 2018), in the sensitivity test 
of 12 financial assets, 12 industries, and 12 real assets in 21 countries over 116 years since 1900 and concluded that all assets perform more, both when the interest rate is higher than their performance when Its decline, and a study (Mehrara \& Karsalari, 2011), applied to 101 developing countries during the period (2007: 1970) showed that there is a weak and unimportant relationship between the private investment rate and the real interest rate, but this relationship is Positive at an interest rate ranging from $5 \%$ to $6 \%$. After this level, the relationship tends to be inverse, and this confirms the seriousness of the high-interest rate.

The Baillie and McMahon (1981) used Granger Causality tests as well as BoxJenkins models to see the impact of three interest rate shocks and GDP for the Federal Republic of Germany during the period 1960 to 1978 on investment. Results indicated that the effect of the rate of investment interest is diverse in two different periods because of the various policy. They determined that investment is inelastic regarding the short-term nominal rate of interest and the same results found in case of the real interest rate. Nevertheless, they also found long-term nominal interest rates influence investment. This result remains the same even after the government shifted its policies about regulating money supply instead of controlling interest rates.

Lanyi and Saracoglu (1983) concluded that the correlation between investment and interest rate was positive. They gathered the data of 21 developing countries, span from 1971 to 1980 , and examine the real financial assets and the growth of actual interest rates. They ended up with a direct association between the growth of tangible financial assets and real interest rates.

However, Ingersoll and Ross (1992) replace discount rate by stochastic interest rate and found that the interest rate uncertainty had adverse impacts on 
investment

Joshua and Delano (1990) conducted a study on the causal factors of private investment in Less Developing Countries on 23 less developing countries for the span 1975 to 1985 . They confirm the result that the real interest rate is inversely related to investment.

Alvareand and Koskef (2003) observed the irretrievable investment with changes in interest rates. This modification in interest rate had a direct and sometimes indirect effect on investment demand.

James and Larsen (2004) studied the effect of rates of lending on real estate investment holding period return in the case of the United States; they found that real estate investment has inversely related to interest rates.

Andrea Beccarini (2007) used the discount factor to exemplify the investment, and the Generalized Movement Method was employed to examine the association between the interest rate and investment in an ambiguous environment; the outcome indicates that the correlation was positive between the interest rate and investment. And the higher instability of the interest rate, the higher the positive correlation would be.

Whuyan et al. (2015) examined the relationship between investment and interest rate in the Jiangsu Province of China. This province is the largest according to investment. Johansen Cointegration test employed for long run nexus. Whereas, for the short-run association, VECM (vector error correction model) is applied over the span from 2003 to 2012. The empirical outcomes indicated that investment and interest rate have a long-term association. The association is negative in the long run; however, the relationship is positive in the short run. It can conclude from the study that reducing the rate promoted investment. However, concurrently, it is detected that the impact of interest rate 
on the investment is quite weak. Apart from the rate of interest, market size, economic development level, investment environment, and preferential policies also impact investment.

lorember and Akighir (2015) employed the quarterly data of interest rate for the Kalman Filtering Technique and Space Modeling between 1999 and 2013. The forecasts of interest rate from out-of-sample showed that the interest rate in Nigeria would hover around the average rate of 18 percent. This trend would be observed from the first quarter of 2014 to the fourth quarter of 2020 . The study concluded that such a level of interest rate is not suitable for the investment condition in the economy, and hence, an efficient policy measure must be introduced. The authors also stressed that the persistent increase in interest rate would adversely affect the Small and Medium Enterprises (SMEs) of the economy.

Bagci and Erguven (2016) performed a Causality and Correlation Analysis to determine the trend direction between the variables of the model. The authors employed the Augmented Dickey-Fuller test, Granger causality tests, and Pearson and Kendall Tau's correlation tests between 2002 and 2015. The result of the study was in contradiction with the well-known fact that the interest rate determines the investment and growth patterns of the economy. Moreover, there was an illusory correlation between the interest rate and growth, and the study found no evidence of an association between these variables as proposed by the economic theory.

Appienti, Ofori, Damptey, and Kusi (2016) incorporated investment, income, interest rate, and inflation employing the data from 1990 through 2014. The study used Co-integration analysis and Stationarity and Causality tests to analyze the association between the variables in the economy of Ghana. The 
findings of Granger causality confirmed a significant, positive, and bidirectional relationship between investment and income. Moreover, the results revealed a significant unidirectional association between income and inflation; and income and interest rate.

Ozturkler et al. (2018) observed the nexus between the real interest rate and investment between 1973 and 2014 in Turkey. The outcomes of the study revealed a unidirectional causality between the variables that move from the interest rate to the private investment in both long run and short run. However, this causality had disrupted during the crises of 1978, 1999, and 2008. Thus, the authors highlighted that expansionary monetary policy would be beneficial to stimulate private investment in Turkey.

Few studies have centered on the economy of Pakistan is examining the causal factors of investment.

Sakr (1993) has studied the determining factors of private investment in the case of Pakistan and determined that the growth rate of GDP, growth of the private sector loans, and public investment are significant factors that determine private investment in the case of Pakistan.

Hyder and Ahmed (2003) investigated the reasons that, why private investment has reduced and how it can fix in the case of Pakistan. They explored that increase in real interest dampens the investment level.

Ahmed (2001) concluded that production, Public Sector Development Plan (PSDP), and interest rate influence net investment. He also established that the PSDP and interest rates are the essential factors of private investment in the case of Pakistan.

Muhammad et al. (2013) analyzed the impact of real interest rate and income on investment in the case of Pakistan. Johansen cointegration test is employed 
to test the Cointegration among the variables for the span of 1964 to 2012 . The results confirmed the economic theory that investment has a negative relationship with the real rate of interest in Pakistan.

Jamil and Muhammad (2015) investigated the impact of the rate of interest on private investment as well as the economic growth of Pakistan. They used timeseries data span from 1980 to 2010 . They as well used a structural equation model to discover the associations among the said variables in the model. The outcomes showed that the labor force, government expenditures, and private investment have a positive and significant impact on GDP; however, FDI has a statistically significant and negative association with GDP. They found a distinctive long term association between the growth of the economy and its factors, including the rate of interest. The outcomes suggest that the behavior of the rate of interest is significant for the growth of the economy. And that's due to the associations between the rate of interest and investment and the growth of the economy.

Afta et al. (2016) explored the long run as well as the short run impact of rate of interest on the private sector credit in case of Pakistan from 1975 to 2011. ADF and P.P. tests used to analyze the Stationary of data. This article used the ARDL model for the aim of examining the long run as well as short-run association. The outcomes confirmed the economic theory that there is a significant negative association between rate of interest and private sector credit in the long term, as well as also in a short time. The outcomes moreover showed a significant positive association between inflation and private sector credit in the long run as well as the short run. But, the exchange rate was detected to have no impact on the private sector credit.

There are two conflicting views on the effect of the real interest rate on the level of 
private investment. A high-interest rate level raises the actual cost of capital and therefore dampens the individual investment level. On the other side, poorly developed financial markets in less developing countries (LDCs) and inadequate access to foreign financing for most private projects, both imply that private investment is constrained mostly by domestic savings. These, in theory, are expected to respond positively to higher real interest rates. For this reason, private investment could, on balance, be positively related to interest rates in developing countries (Greene and Villanueva, 1990).

As for previous empirical studies, because of the significant number of these studies, five of them were chosen. The first study conducted by Greene and Villanueva (1990). They explored the determinants of private investment in less developing countries for 23 countries over the 1975-1987 period. They found that the real deposit interest rate has a negative impact on private investment. The second study by Hyder and Ahmad (2003) was about the slowdown in private investment in Pakistan. They found that higher real interest rates reduce private investment. Larsen (2004), in the third study about the United States, has found that low mortgage interest rates make direct real estate investments attractive to suppliers of the real estate units. Aysan and others (2005), in the fourth study, analyzed the determinants of unsatisfying private investment growth in the Middle East and North Africa (MENA) throughout the 1980s and 1990s. Their findings have shown that the real interest rate appears to exert a negative effect on firm investment projects. And in the last study, Wang and $\mathrm{Yu}$ (2007) examined the role of interest rate in investment decisions for firms in Taiwan. Their results reveal that the interest rate plays a vital role in investment decisions. 


\section{Commentary on previous studies:}

Most of the studies in the literature covered by this study concentrate on proving the relationship between the interest rate and investment, and the existence of a non-linear relationship between the interest rate and investment and change from positive to negative according to interest rate rates at both, the micro and macro level of the analysis including (Lugo, 2008), Alvareand and Koskef (2003), Whuyan et al. (2015), Greene and Villanueva (1990), Larsen (2004), Hyder and Ahmad (2003), and the others mentioned in the literature review in this study.

Furthermore, most of the previous studies implemented cointegration approach to investigate the existence of the long-run relationship among interest rate and investment, which shows association among variables but do not show the causation and its direction between variables "association does not mean causation", while there is a new line of empirical studies adopted new techniques in investigating long-run association and causation, such as, ARDL, Bound Testing, and others.

\section{Empirical Analysis}

3.1 Model Specification and Data

To investigate the relationship between the interest rate and investment, we used annual data during the 1980-2018 periods. The data obtained from the World Bank: World Development Indicators for Egypt. We transformed the data into a logarithm. Figure (1) shows the data where (LINT) is the interest rate in logarithm, and (LINV) is the investment in logarithm. 


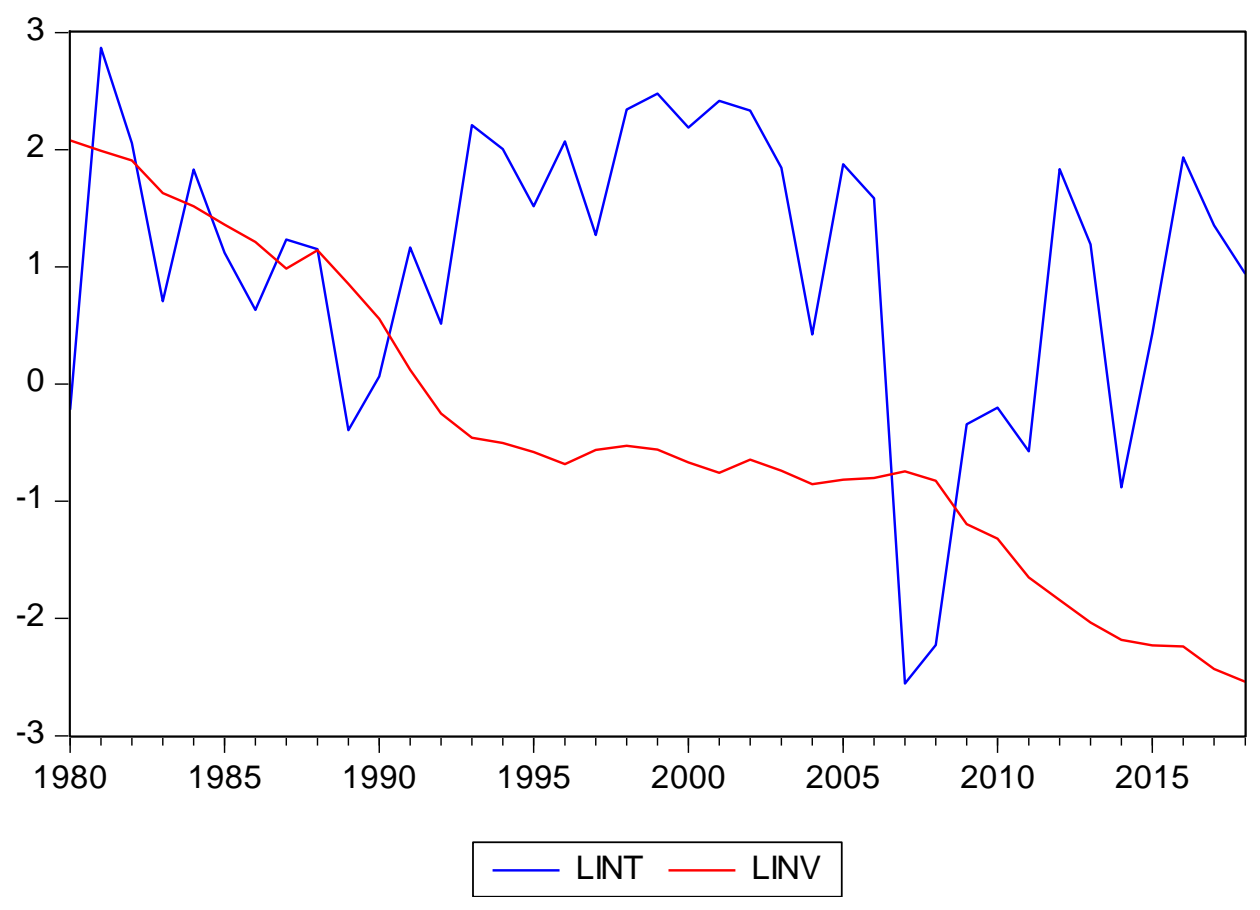

Figure (1). Interest rate and Investment in Egypt

Nelson and Plosser (1982) argued that almost all macroeconomic time series are not stationary at level (have unit root). So, series will be examined using Augmented Dickey-Fuller (ADF) and Phillips, Person tests.

Autoregressive Distributed Lag (ARDL)-Bounds testing approach, which was primarily introduced by Pesaran and Shin (1990), then has extended by Pesaran et al. (2001), used to investigate the presence of Cointegration between two series. Unlike Johansson Joint Cointegration Test, ARDL does not require the integration of time series at the same order. So, it can be applied using either $\mathrm{I}(0)$ or $\mathrm{I}(1)$ series or both $\mathrm{I}(0)$ and $\mathrm{I}(1)$, but not $\mathrm{I}(2)$ according to Pesaran et al. (2001), where I(.) indicates the degree of integration for the series. F-test value in the boundary test compared to the values developed by Pesaran et al. (2001). The Null Hypothesis is: there is no long-run Cointegration between the variables, while the alternative hypothesis indicates that there's Cointegration. If the value 
of the F-test is higher than the upper limit, the Null Hypothesis can be rejected. In case it is less than the lower threshold, this indication to the absence of the Cointegration between the variables. Suppose the value of the F-test is in between the upper and lower limits. No decision can be taken. Then error correction term obtained from the ARDL model will be examined to show the speed of adjustment at which the model reverses to equilibrium after the shocks happened in the short-run.

The model will be applied twice. First, while LINV is a dependent variable as follow:

$$
\begin{aligned}
\Delta L I N V=\partial_{0} & +\sum_{i=1}^{p} \partial_{i} \Delta L I N V_{t-i}+\sum_{i=1}^{q} b_{i} \Delta L I N T_{t-i}+\delta_{0} L I N V_{t-1}+\delta_{1} L I N T_{t-1} \\
& +\varepsilon_{t}
\end{aligned}
$$

Where,

$\delta_{0}, \delta_{1}$ show the coefficients of the long-run relationship between the series;

$\partial_{i}$ and $b_{i}$ show the coefficient of the short-run relationship between the series.

$\Delta$ Is defined as the first difference operator.

Null Hypothesis $H_{0}: \delta_{0} \neq \delta_{1} \neq o$

$$
H_{1}: \delta_{0} \neq \delta_{1} \neq o
$$

"P" impersonates the lag length of LINV, and "q" impersonates the lag length of the LINT series.

Second, LINT is a dependent variable as follow; 


$$
\begin{gathered}
\Delta L I N T=\partial_{0}+\sum_{\substack{i=1\\
}}^{p} \partial_{i} \Delta L I N T_{t-i}+\sum_{i=1}^{q} b_{i} \Delta L I N V_{t-i}+\delta_{0} L I N T_{t-1}+\delta_{1} L I N V_{t-1} \\
+\varepsilon_{t}
\end{gathered}
$$

Where

$\delta_{0}, \delta_{1}$ show the coefficients of the long-run relationship between the series;

$\partial_{i}$ and $b_{i}$ show the coefficient of the short-run relationship between the series.

$\Delta$ Is defined as the first difference operator.

Null hypothesis, $H_{0}: \delta_{0} \neq \delta_{1} \neq o$

$$
H_{1}: \delta_{0} \neq \delta_{1} \neq o
$$

"P" impersonates the lag length of LINT, and "q" impersonates the lag length of the LINV series.

The error correction model has established as follow for model 1 and model 2 , respectively;

$$
\begin{aligned}
& \Delta L I N V=b_{0}+\sum_{i=1}^{p} b_{i} \Delta \operatorname{LINV}_{t-i}+\sum_{i=0}^{q} \partial_{i} \Delta \operatorname{LINT}_{t-i}+\varphi \operatorname{ECM}_{t-i}+\epsilon_{t} \\
& \Delta L I N T=b_{0}+\sum_{i=1}^{p} b_{i} \Delta \operatorname{LINT}_{t-i}+\sum_{i=0}^{q} \partial_{i} \Delta L I N V_{t-i}+\varphi E C M_{t-i}+\epsilon_{t}
\end{aligned}
$$

Where

ECM is the error correction term, 
$\varphi$ represents the speed of adjustment at which the model reverts to long-term equilibrium after the shocks happened in the short-run.

\section{Empirical results}

\subsection{Unit Root Tests}

ADF, P.P. tests used to investigate the stationarity of series, and null hypotheses claim that series contains a unit root (non-stationary). The result is summarized in table (1) and table (2) for LINT and LINV, respectively.

Table (1). PDF, P.P. Stationary Test Results for LINT.

\begin{tabular}{|c|c|c|c|c|}
\hline \multicolumn{5}{|c|}{ Augmented Dicky Fuller (ADF) results } \\
\hline \multicolumn{3}{|l|}{ At Level } & \multicolumn{2}{|c|}{ At first difference } \\
\hline & t-statistic & Prob. & t-statistic & Prob. \\
\hline With constant & -3.767313 & 0.0068 & -3.976588 & 0.0181 \\
\hline With constant \& trend & -3.976588 & 0.0181 & -8.342700 & 0.0000 \\
\hline \multicolumn{5}{|c|}{ Philips, Person, test results } \\
\hline \multicolumn{3}{|l|}{ At Level } & \multicolumn{2}{|c|}{ At first difference } \\
\hline & t-statistic & Prob. & t-statistic & Prob. \\
\hline With constant & -3.845356 & 0.0055 & -8.666206 & 0.0000 \\
\hline With constant \& trend & -4.062030 & 0.0147 & -8.565741 & 0.0000 \\
\hline
\end{tabular}

The results indicate that (LINT) is not stationary at level, but after taking the first difference, it became stationary at 5\%. Table (2) summarized the results of ADF \& P.P. tests for (LINV).

Table (2). PDF, P.P. Stationary Test Results for LINV.

Augmented Dicky Fuller (ADF) results 


\begin{tabular}{|l|l|c|l|l|}
\hline \multicolumn{4}{|l|}{ At Level } & \multicolumn{2}{l|}{ At first difference } \\
\hline & $\mathrm{t}$-statistic & Prob. & t-statistic & Prob. \\
\hline With constant & -1.088806 & 0.7100 & -4.176901 & 0.0023 \\
\hline With constant \& trend & -2.039232 & 0.5613 & -4.172231 & 0.0114 \\
\hline Philips, Person, test results & t-statistic & Prob. & t-statistic & Prob. \\
\hline At Level & -0.972248 & 0.7533 & -4.142763 & 0.0025 \\
\hline & -1.789678 & 0.6900 & -4.138708 & 0.0124 \\
\hline With constant & With constant \& trend & -5 first difference \\
\hline
\end{tabular}

It is clear that (LINV) is not stationary at level, but after taking the first difference, it became stationary at $5 \%$. According to the results above, LINC, LINV are integrated in the first order (1). Since the variables integrated at the primary level, and none of them is I(2), then we can apply ARDL as follow:

\subsection{ARDL MODEL}

Since both LINC and LINV are I(1), we used two ARDL models with considering LINV as the dependent variable in the first model and LINC as the dependent variable in the second one.

Table (3) represents the ARDL bound testing outcome while LINV is dependent variable model 1 , the selected model was: ARDL $(1,1)$.

Table (3). F-Bound Test, long-run coefficient, and error correction term. Model $(1)$.

\begin{tabular}{|l|l|l|l|l|}
\hline \multicolumn{4}{|l|}{ Levels Equation } \\
\hline Case 2: Restricted Constant and No Trend \\
\hline Variable & Coefficient & Std. Error & t-Statistic & Prob. \\
\hline
\end{tabular}




\begin{tabular}{|c|c|c|c|c|}
\hline LINT & 1.839838 & 0.757653 & 2.428339 & 0.0214 \\
\hline C & -4.952701 & 1.720777 & -2.878177 & 0.0073 \\
\hline \multicolumn{2}{|c|}{ F-Bounds Test } & \multicolumn{3}{|c|}{ Null Hypothesis: No levels relationship } \\
\hline \multirow[t]{2}{*}{ Test Statistic } & Value & Signif. & $\mathrm{I}(0)$ & $\mathrm{I}(1)$ \\
\hline & & & $\begin{array}{l}\text { Asymptotic: } \\
\mathrm{n}=1000\end{array}$ & \\
\hline F-statistic & 18.71625 & $10 \%$ & 3.02 & 3.51 \\
\hline \multirow[t]{3}{*}{$\mathrm{k}$} & 1 & $5 \%$ & 3.62 & 4.16 \\
\hline & & $2.5 \%$ & 4.18 & 4.79 \\
\hline & & $1 \%$ & 4.94 & 5.58 \\
\hline \multicolumn{5}{|c|}{ ECM Regression } \\
\hline \multicolumn{5}{|c|}{ Case 2: Restricted Constant and No Trend } \\
\hline Variable & Coefficient & Std. Error & $\mathrm{t}-$ Statistic & Prob. \\
\hline $\mathrm{D}(\operatorname{LINT}(-1))$ & -0.047987 & 0.018363 & -2.613264 & 0.0139 \\
\hline CointEq(-1)* & -0.047235 & 0.006104 & -7.738992 & 0.0000 \\
\hline
\end{tabular}

*significant at $1 \%$

The value of the F-test $(65.17005)$ is sharply higher than the upper limit at all significance levels. This indicates the presence of long-run Cointegration between the investment and interest rate; the long-run coefficient of LINT is statistically significant. The error correction term is negative and statistically significant $(-0.750767)$ is the coefficient of ECM, which indicates the speed of LINV to come back to long-run equilibrium with LINT.

Table (4) represents the F-Bounds test long-run coefficients and error correction term, model 2, while LINT is the dependent variable. 
Table (4). F-Bound Test, long-run coefficient, and error correction term. Model $(1)$.

\begin{tabular}{|c|c|c|c|c|}
\hline \multicolumn{5}{|c|}{ Levels Equation } \\
\hline \multicolumn{5}{|c|}{ Case 2: Restricted Constant and No Trend } \\
\hline Variable & Coefficient & Std. Error & t-Statistic & Prob. \\
\hline LINV & -2.817028 & 12.74812 & -0.220976 & 0.8267 \\
\hline C & -7.026710 & 35.50548 & -0.197905 & 0.8445 \\
\hline \multicolumn{2}{|c|}{ F-Bounds Test } & \multicolumn{3}{|c|}{ Null Hypothesis: No levels relationship } \\
\hline \multirow[t]{2}{*}{ Test Statistic } & Value & Signif. & $\mathrm{I}(0)$ & $\mathrm{I}(1)$ \\
\hline & & & $\begin{array}{l}\text { Asymptotic: } \\
\mathrm{n}=1000\end{array}$ & \\
\hline F-statistic & 1.469394 & $10 \%$ & 3.02 & 3.51 \\
\hline \multirow[t]{3}{*}{$\mathrm{K}$} & 1 & $5 \%$ & 3.62 & 4.16 \\
\hline & & $2.5 \%$ & 4.18 & 4.79 \\
\hline & & $1 \%$ & 4.94 & 5.58 \\
\hline \multicolumn{5}{|c|}{ ECM Regression } \\
\hline \multicolumn{5}{|c|}{ Case 2: Restricted Constant and No Trend } \\
\hline Variable & Coefficient & Std. Error & t-Statistic & Prob. \\
\hline $\mathrm{D}(\operatorname{LINV}(-1))$ & -2.671066 & 1.146670 & -2.329411 & 0.0270 \\
\hline CointEq(-1)* & -0.059888 & 0.027588 & -2.170759 & 0.0383 \\
\hline
\end{tabular}

*significant at $10 \%$

The finding revealed, F-test is higher than the upper limit at $10 \%$; the long-run coefficient is statistically significant, and the error correction term is negative and significant at $10(-\mathbf{1 . 1 8 8 5 9 9})$, which indicates the speed of LINT to come back to a long-run relationship with LINV. 
To detect the causal relationship in the short-run, we have used the Pairwise Granger Causality Tests.

\subsection{Causality Test}

Pairwise Granger Causality Tests

Sample: 19802018

Lags: 3

Null Hypothesis: Obs F- StatisticProb.

\begin{tabular}{llll}
\hline \hline LINT does not Granger Cause LINV & 36 & 3.72815 & 0.0221 \\
LINV does not Granger Cause LINT & 1.97998 & 0.1390
\end{tabular}

The results of the Pairwise Granger Causality Tests showed that we could not accept the null hypothesis, which indicates that $\mathrm{D}(\mathrm{LINT})$ does not granger cause $\mathrm{D}(\mathrm{LINV})$, because the probability value was less than $5 \%$. In contrast, we can accept the null hypothesis, which indicates that $D($ LINV) does not granger cause $\mathrm{D}(\mathrm{LINT})$, because the probability value was higher than $5 \%$.

\section{Conclusion and Recommendations}

The empirical analysis came up with the following conclusions:

a) For model 1, the ARDL bound testing outcome, while LINV is the dependent variable, the value of the F-test $(65.17005)$ is strongly higher than the upper limit at all significance levels. This indicates the presence of long-run Cointegration between the investment and interest rate; the 
long-run coefficient of LINT is statistically significant. Also, the error correction term is negative and statistically significant $(-0.750767)$ is the coefficient of ECM, which indicates the speed of LINV to come back to long-run equilibrium with LINT.

b) For model 2, the ARDL bound testing outcome. At the same time, LINT is the dependent variable, the finding revealed, F-test is higher than the upper limit at $10 \%$. The long-run coefficient is statistically significant, and error correction term is negative and significant at $10(-\mathbf{1 . 1 8 8 5 9 9})$, which indicates the speed of LINT to come back to a long-run relationship with LINV.

c) The interest rate granger causes investment, which is our primary concern for this research.

As for the recommendations of the research, for the state policymakers, the Egyptian government advised reconsidering many of the general state policies, including investment policies, financial and administrative governance, and monetary policy that focuses on maintaining a balanced interest rate that improves and motivate the investment environment. As a result, this will enhance both the domestic investment and the foreign direct investment flows into Egypt.

scope for future researches: Researchers are advised to conduct further studies and scrutinize other political, social, and demographic variables that may affect investment demand, as well as to use new econometric models that would give more accurate and reliable results. 


\section{References}

Afta, Nadeem, Khalil Jebran, Irfan Ullah, and Muhammad Awais (2016). Impact of Interest Rate on Private Sector Credit: Evidence from Pakistan." Jinnah Business Review, 4(1): 47-52.

Ahmed, Qazi Masood (2001). The Influence of Tax Expenditures on Nonresidential Investment. Journal of development economics, 65: 477-489.

Alvarez, Luis Hernan Radomiro, and Erkki Koskela (2003). Irreversible investment under interest rate variability: new results. Finland: Bank of Finland Discussion Papers, 1-27.

Appienti, William Ansah, Daniel Ofori, Augustine Owusu Damptey, and Anthony Kusi (2016). Key Determinants of Investment in Ghana: Cointegration and Causality Analysis. European Journal of Business, Economics, and Accountancy, 4(5): 41-49.

Aysan, A., Gaobo, P., and Marie-Ange Veganzones-Varoudakis (2005). How to Boost Private Investment in the MENA Countries: The Role of Economic Reforms. Topics in Middle Eastern and North African Economics, MEEA, Online Journal, (VII): $1-15$.

Bader, Majed, and Ahmad Ibrahim Malawi (2010). The impact of interest rate on investment in Jordan: a cointegration analysis. Journal of King Abdulaziz University: Economics and Administration, 24(1): 199-209.

Bağci, Erdem, and Emre Ergüven (2016). Relations between Interest Rate, Inflation, Growth, and Investment in Turkey, 2002-2015. Journal of Economics and Finance, 7(5): 43-49.

Baillie, Richard T., and P. C. McMahon (1981). Interest rates and investment in West Germany. Empirica Economics, 6(1): 1-9. 
Beccarini, Andrea (2007). Investment sensitivity to interest rates in an uncertain context: is a positive relationship possible?. Economic Change and Restructuring, 40(3): 223-234.

Dickey, D. A., \& Fuller, W. A. (1981). Likelihood Ratio Statistics for Autoregressive Time Series with a Unit Root. Econometrica, 49(4): 10571072.

Dimson, E., Marsh, P.\& Staunton, M. (2018). Credit Suisse Global Investment Returns Yearbook 2018, s.1.: Credit Suisse Research Institute, 7 (13)

Egyptian Central Bank, several issues (2010-2016)

Greene, J., and Villanueva, D. (1990). Determinants of Private Investment in LDCs. Finance and Development Handbook of Statistics 42, North-Holland Publication. Hyder, Kalim, and Qazi Masood, Ahmed (2003). Why private investment in Pakistan has collapsed and how it can be restored. The Lahore Journal of Economics, 9(1): 107-128.

Ingersoll Jr, Jonathan E., and Stephen A. Ross (1992). Waiting to invest: Investment and uncertainty. Journal of Business, 65(1): 1-29.

Greene, Joshua, and Delano Villanueva (1990). Determinants of private investment in LDCs. (Finance and Development 27, no. 4: 40.

Greene J.\& Villanueva, D. (1991). Private Investment in Developing Countries: An Empirical Analysis. Staff papers International Monetary Fund,38(1), 37$38,53-54$

lorember, Paul T., and David Terfa Akighir (2015). "State Space Modelling and Kalman Filtering of Interest Rate in Nigeria: Implications for Investment." (JESR VOL 6, NO. 1, 01-18. 
Jamil, Naveed Iqbal Muhammad Farooq (2015)). Interest Rates, Government and Private Investments and Pakistan Economy: An Analysis of Three Decades. (International Journal of African and Asian Studies Vol.14, 161-166

Joshua Greene and Delano Villanueva (1991). IMF Staff Papers, vol. 38, issue $1,33-58$

Lanyi, Anthony, and Rüsdü Saracoglu (1983). The importance of interest rates in developing economies. (Finance and Development 20, no. 2, 20.

Larsen, James E. (2004). The impact of loan rates on direct real estate investment holding period return. (Financial Services Review, 13, no. 2, 111. Lugo, O.M. (2008). The differential impact of real interest rates and credit availability on private investment: evidence from Venezuela BIS, Volume 31, 503-504.

Muhammad, D. Sulaiman, Rasool Lakhan, Saba Zafar, and Muhammad Noman (2013). Rate of Interest and its Impact on Investment to the Extent of Pakistan. (Pakistan Journal of Commerce and Social Sciences, 7, no. 1 91-99.

Nelson, C. R., \& Plosser, C. R. (1982). Trends and random walks in macroeconomic time series: some evidence and implication. Journal of Monetary Economics, 10 (2), 139-162.

Mehrara, M.\&Karsalari, A.R. (2011). The Nonlinear Relationship between Private Investment and Real Interest Rates Based on Dynamic Threshold Panel: The Case of Developing C0untries Journal of Money, Investment and Banking, 21, $32-42$ 
Osundina\&Osundina (2014). Interest Rate as a Link to Investment Decision in Nigeria (Mundell - Flemming Model ). Journal of Economics and Finance,2 (4), 13

Öztürkler, Harun, Bülent Güloğlu, and Arş Gör Murat Güven (2018). "Interest Rate and Time Series Analysis of the Relationship Between Private Investment in Turkey." (Journal of Economic Research 1, no. 1, 148-157.

Pesaran, M. H., \& Shin, Y. (1999). Pooled mean group estimation of dynamic heterogeneous panels. Journal of the American Statistical Association, 94 (446), 621-634.

Pesaran, M. H., \& Shin, Y., \& Smith, R. J. (2001). Bounds testing approaches to the analysis of level relationships. Journal of applied econometrics, 16 (3), 289-326.

Philips, P. C., \& Perron, P. (1988). Testing for a unit root in time series regression. Biometrika, 75 (2), 335-346.

Sakr, Khaled. Determinants of private investment in Pakistan (1993). (IMF Working Paper 1-20.

Sharpe, S.\&Suarez, G. (2015).Why isn't Investment More Sensitive to Interest Rates: Evidence from Surveys, Washington, D.C.: Federal Reserve Board, 31,32

Wang, D.H. and Yu, T.H. (2007) "The Role of Interest Rate in Investment Decisions: A Fuzzy Logic Framework," Global Business and Economic Review, 9(4), (September): $448-457$. 
Wuhan Suyuan, L.\&Khurshid, A. (2015). The effect of interest rate on investment: Empirical evidence of Jiangsu Province, China. Journal of international studies, $8(1), 81-90$ 